УДК 392.51(496.5=163.3)(049.3)

https://doi.org/10.55302/MF2077-78155j

Андријана Јаневска

\title{
СВАДБЕНИОТ ОБРЕДЕН КОМПЛЕКС КАЈ МАКЕДОНЦИТЕ ОД МАЛА ПРЕСПА
}

Апстракт: Свадбата е еден од најважните моменти во животот на човекот. На тој ден најмногу се пее и се игра.

Свадбата како обред на премин, во Македонија претставува жива традиција, која чува бројни и разни докази како за општествените односи на традиционалната заедница, така и за промените на овој сложен семејно-обичаен и обреден циклус. Свадбата и свадбените обичаи, обреди и песни спаѓаат во групата свечености поврзани за животниот циклус.

Свадбениот обреден комплекс содржи остатоци од карактеристиките на општествениот живот во минатото.

Клучни зборови: свадбен обреден комплекс, обредно време, обреден простор, Мала Преспа, свадбено пеење.

Еден од најсложените обреди по својата структура на обредите од животниот циклус е свадбата. Свадбениот обреден комплекс содржи остатоци од карактеристиките на општествениот живот во минатото. Според Величковска, „за овој комплекс својствено е тоа што изобилува со голем број обредно-магиски дејствија во чија основа стои апотропејскиот карактер. При самиот чин на свадбата најмногу се внимавало младоженците да не паднат под влијание на „лоши очи“ и разни магии со негативни последици (Величковска, 2008, 55).

Според Пенушлиски, „иако не може да се зборува за постоењето на вистинска драма во свадбата, таа сама по себе се наметнува од големиот број учесници во свадбениот ритуал - учесници што имаат точно определени улоги, во определено време и на определено место, потем од конфликтот што е неминовен поради разделбата на невестата од родителскиот дом и нејзиното стапување во домот на младоженецот како негов нов член, иако конфликтот почесто се изразува со песни отколку низ дијалози и реплики итн. Драмската постановка на свадбата произлегува и од синкретската состојба на свадбениот обред во целина (Пенушлиски, 2012, 131).

Главни личности во свадбениот церемонијал, освен невестата и младоженецтот се: кумот, старосватот, братот на невестата, деверот и други учесници, кои се викаат сватови. За нив, во текот на целиот свадбен ритуал, истакнува Величковска, се пеат песни, поврзани со целокупниот обреден процес и имаат точно одредено обредно место и време на изведба: „Се пеат песни кога: се плете рогозината или венците, кога се меси обредниот леб „погача“ („на замесок“), кога се бричи младоженецот, кога ѝ ги плетат 
плетенките на невестата, кога „огледниците“ доаѓаат да ја видат невестата, кога сватовите пристигнуваат кај девојката, кога невестата ја водат по пат во куќата на момчето, кога невестата влегува во дворот на младоженецот, кога ја изведуваат невестата пред свекорот и свекрвата за време на дарувањето на сватовите и сл. (Величковска, 2016, 42-43).

Свадбата како обред на премин кај Македонците претставува жива традиција, која чува бројни и разни докази како за општествените односи на традиционалната заедница, така и за промените на овој сложен семејнообичаен и обреден циклус.

Весна Петреска во студијата за свадбата како обреди на премин кај Македонците од брсјачката етнографска целина прави анализа на свадбата во контекст на теоријата на обредите на премин, поврзувајќи ги свадбените обичаи во нивната изразеност, функција и значење, истакнувајќи при тоа дека преминот што треба да го извршат индивидуите, со свадбата, се одвива постепено, а клучните моменти што се значајни за извршениот премин успешно, се изразуваат на ниво на целокупниот свадбен обреден комплекс носија обреди и песни (Петреска, 2002, 10). При идеалтипското претставување на свадбените обреди кај Брсјаците во посочените предели, таа прави дескрипција на материјалите од теренските истражувања, истакнувајќи ги при тоа најзначајните моменти од свадбата, како што се: претсвадбени обичаи; подготовка на свадба; свадбени обичаи и посвадбени обичаи ${ }^{1}$ Свадбениот обред е обред на премин, кој секако е најизразен за невестата и младоженецот, но овој премин е исто така карактеристичен и за двете семејства, како и за одредени личности од свадбениот церемонијал, кои, со овој чин, стануваат роднини по некрвно сродство (Петреска, 2000, 369).

Предмет на истражување во овој труд е идеалтипското претставување на свадбениот обреден комплекс како дел од сѐ уште живата обредна и обредно-пејачка традиција кај Македонците од Мала Преспа за да се истакнат најзначајните моменти од свадбениот обреден церемонијал во посочениот регион.

Во оваа пригода ќе се повикаме на книгата Мала Пресnа на Гуре Дума, кој ја напишал врз база на расказите на стари луѓе од сите села на Мала Преспа, а особено од раскажувањата на неговиот татко Пандо.

Веридбата на младите во Мала Преспа се вршела без да се прашаат тие со кого сакаат да стапат во брак. Се случувало невестата и младоженецот да се запознаат дури на денот на свадбата. Постојат податоци дека тие се вереле многу млади, речиси деца. Според податокот на Дума, „имало случаи кога се вршело веридба уште кога децата биле во пелени. Тоа се случувало меѓу комшии и пријатели, кои имале добри односи, па постарите, особено жените, во тајност ќе сменеле дарови и ќе го даделе зборот кога ќе пораснат децата да се земаат за маж и жена“ (Дума, 2007, 85).

\footnotetext{
${ }^{1}$ Подетаљно за свадбата и за свадбените обреди на премин кај Брсјаците видете кај Весна Петреска (Петреска, 2002).
} 
Стројникот бил некој близок на семејството од кое се барала невестата, a се праќал од страна на зетот. Вообичаено му давале пари, „дулбен“2 или ѓердан, а потоа тој со даровите одел кај фамилијата на невестата. Постоел еден интересен адет со кој стројникот требало да го кандиса сватот. Имено, откако ќе стигнел таму, седнувал до „кланикот“33 и го буричкал огнот. Најнапред тие се договарале за веридбата, а на крајот стројникот ги давал парите и даровите од идниот сват. Нему, пак, од страната на невестата му дарувале чевли.

Во следниот период, вообичаено било двете фамилии меѓусебно да си разменуваат дарови. Па така, стројникот повторно качен на бел коњ, со даровите наполнети во шарени торби одел кај фамилијата на невестата: „Во торбите се носело руба како шегун ${ }^{4}$, кошули, платнени фустани, гушарки, волнена вишна шамија, шкепе, ресачка, кусале и др., и накит како костек, синџир, ѓердан, туртулици за на чело, обетки, прстени и др.“ (Дума, 2007, 85). Но, и од страната на невестата се носеле дарови за фамилијата на зетот: платнени кошули за свекорот и свекрвата, чорапи за деверите, „месали“5 $а$ јатрвите и др. Освен нив, се дарувале и: дедото, бабата, мајката, таткото, браќата и сестрите.

Потоа, десетина повозрасни луѓе од страната на зетот, качени на коњи, оделе кај сватот: „Ке наседнеле околу софрите со разни мезиња, и главниот од групата ќе прашал: Свату, колку ти е ако (цената) на невестата? 15 наполони, ти одговара?, ке одговорел другиот сват. И кога ќе се договореле, ќе го определеле денот на свадбата. Младите седеле верени и по пет години, бидејќ́ од економски причини не им се правело свадба““ (Дума, 2007, 86).

Вообичаено свадбата, заедно со првичето ${ }^{6}$ траела и повеќе од една седмица. Се започнувало во понеделник, додека пак во вторник се земале поседарките. ${ }^{7}$ Во среда се месела погачата, а во четврток се пазарувале свирбите $^{8}$ и се канеле подалечните пријатели. Во петок се колел јунец ${ }^{9}$, додека рано наутро во сабота, две-три дечиња оделе низ селото делејќи кравајчиња и вино $^{10}$ велејќ: Да повелите да ни дојте на брак! Селаните, пак, им одговарале со зборовите: Сполај ви, па на ваши главје!

\footnotetext{
${ }^{2}$ Според моите истражувања, станува збор за дулба - (арх.) вид турска златна пара во вредност од две златни лири, која се употребува и како украсен предмет.

${ }^{3}$ Место покрај огништето, каде што се чуваат дрвата.

${ }^{4}$ Облека од типот зубун - составен дел на рамничарско-земјоделска женска носија.

5 „Месалија“ - ткаена крпа од волна и од памук со која се завиткува тестото за да стаса.

${ }^{6}$ Првичето било прослава со играње и со пеење по свадбата, но со помалку луѓе. Во Мала Преспа, домашните и поблиските луѓе од страна на зетот оделе на првиче во понеделникот, ден по свадбата. Во вторникот, пак, роднините на невестата доаѓале кај зетот на првиче.

${ }^{7}$ Тоа се женски деца на браќата и сестрите на домаќинот, кои ги вршеле сите работи потребни за свадбата: готвење, чистење, миење.

${ }^{8}$ Свирачи.

${ }^{9}$ Но, можело да биде ситен добиток за месо за свадбата.

${ }^{10}$ Виното го носеле во плоска (карта).
} 
Во саботата попладне, девојките од селото се собирале кај невестата и со насолзени очи се простувале со бакнување. Потоа тие ја кршеле погачата и им ја делеле на присутните во дворот. Свирачите доаѓале во саботата навечер кога се собирало целото село. Адет било, свекрвата со погача на главата, заедно со поседарките, да заврти оро неколку пати во дворот. ${ }^{11}$ Најнапред пристигнувале подалечните гости, а потоа гостите од селото. На софрите во дворот имало точно утврден ред на седење: од едната страна седеле мажите, а од другата жените, наредени по старост. Најпочитуван на свадбата бил кумот, кој го земале со свирачи пред да се соберат бракарите. Но, и братимите (побратимите), кои вообичаено биле два-тројца, биле многу почитувани.

Во целокупниот свадбен обреден процес кај Македонците од Мала Преспа, се пееле песни, кои имаат точно определено обредно место и време на изведба.

Во рамките на моите теренски истражувања во Мала Преспа во октомври 2014 година, пејачките Олга Ташовска, Катерина Ташовска и Трена Грозданова од селото Пустец, покрај бројните информации околу свадбата и свадбеното пеење, ме информираа дека свадбените песни ги нарекуваат „бракарски“. Една од нив ми го објасни начинот на пеење: Постолица викаше, а јас и Цветкоица вржеме. Една од бракарските песни е „Шенвај се, мајко, шенвај се“, која ѝ ја пееле на девојката во последната седмица пред свадбата кога таа се подготвува за мажење (Видете го прилогот со нотен и текстуален пример).

Пред свадбата, во домот на младоженецот се виел венец за невестата, а во нејзиниот дом венец за младоженецот. Чинот на плетење на венецот бил најава за свадбата. Во истиот се ставала прачка од винова лоза (за младите да бидат вечни), продукти од бела пченица (за да бидат плодни), босилок и китки (за да бидат здрави). Во Мала Преспа, „венецот и капата ги шиеле братимите. Венецот се шиел со 'рженица и се украсувал со босилок, клаподан, црвено предно, шеќерчиња и др. На капата, од десната страна, се шиела жолтица, која ќе била наполеон или лира. Штом ќе почнело шиењето на венецот и на капата, група девојки ќе се исправеле до братимите и ќе почнеле да пеат до завршувањето на шиењето (Дума, 2007, 87)“. Еве една од песните што се пееле додека се шиеле венецот и капата ${ }^{12}$ :

\section{Марко коња кова рано во недела со сребрени плочи со златени клинци}

Марку коња му говори, Марко, Марко, мој стопане зошто толку мене коваш уште рано во недела дали ќе ме носиш, Марко, мене да ме продадеш Марко коњу тивко му говори, коњу, мили коњу, драги, не те ковам за продање, тук те ковам за патување,

\footnotetext{
${ }^{11}$ Овој адет се нарекува играње на погачата.

12 Во куќата на зетот, пак, во саботата навечер се пеела песната „Месечино Мароле“. Тогаш се подготвувале венците и на капата на младоженецот му шиеле една венецијанска стара кована пара или златник, во зависност што имале.
} 
далеко ќе појме либе да довеме

мајка да одмена од тешките ношви

сестра да одмена од шарени стомни.

„Штом ќе завршело шиењето на венецот и капата“, истакнува Дума, „сите гости ќе станеле на нозе и ќе го молитвеле (наздравеле) домаќинот за среќa на младите. Церемонијата продолжувала доцна во ноќта со играње и пеење“" (Дума, 2007, 87).

Утрото, пред да се тргне по невестата, братимите го бричеле зетот. До нив имало група девојки, кои пееле до завршувањето на бричењето:
Ајде, ме угрело, ме угрело летно сонце, во Солунско, Солунско равно поле, ајде, не ми било, не ми било летно сонце, ајде, тук ми било, тук ми било малој моме, ајде, малој моме, малој моме жетва жние, ајде, песна пее, песна пее гласовита, ајде, гласо држи, гласо држи три полиња, ајде, три полиња, три полиња три мориња.

Во неделата утрото, откако ќе завршеле со бричењето на зетот, неколку млади бракари оделе низ селото да бараат коњи за останатите бракари што немале коњи. Вообичаено немало проблем бидејќи на секој од селото му било чест да помогне. Најнапред ги подготвувале коњите на тој начин што ги врзувале низ дворот, им ставале веленца ${ }^{13}$ на самарите и полека се подготвувале за одење по невестата. Најнапред во стројот одел свекорот, па кумот, па братимите итн. ${ }^{14}$ Постариот братим ги носел венецот и капата. На свадбите во Мала Преспа се носел бајрак, кој бил во форма на крст. Вообичаено го носело детенце, кое, по џебовите, имало закачено јаболка со дулбенче. Никогаш не се веело државно знаме бидејќи Мала Преспа секогаш била поробена.

Според Дума, „кога ќе се приближеле до селото од каде што била невестата, еден од свадбарите со неговиот коњ ќе одел понапред од другите, ќе влезел во дворот од куќата на невестата со плоската во рацете и ќе го вртел коњот дури да јавнел домаќинот, па ќе ги сменеле плоските и свадбарот ќе се врател назад кај другите свадбари. Овој адет се правел за да му се кажело на сватот дека сватовите се во близина, а свадбарот со плоската се викал мустулџија [...] Кога ќе се доближеле сватовите до куќата, било обичај невестата некаде да биде сокриена и преку копринено сито или прстен да си го види момчето“ (Дума, 2007, 88).

Откако сватовите ќе седнеле во куќата на невестата, обичај бил, сестрата на невестата ${ }^{15}$ да го бакне зетот подарувајќ́ му риза, а тој ѝ давал

\footnotetext{
13 Мал килим, килимче.

14 Свекрвата никогаш не одела по невестата.

${ }^{15}$ Ако немала сестра, тогаш брачеда (братучетка).
} 
јаболко. Бидејќи невестата била боса, ѝ ги носеле чевлите на свекорот со кои таа требало да дојде кај сватовите. Кога ќе се појавела невестата, застанувала среде соба. Потоа ќе се приближеле двајца сватови и ја кршеле погачата над главата на невестата. Секој ја земал за себе својата половина. Потоа се доближувал свекорот, ги земал своите чевли и ги ставал пред неа чевлите на невестата. Тогаш ја дарувал со пари, а во таа пригода се пеела песната „Растреси се свекре, море“. Потоа доаѓал стариот братим, кој ги ставал превезот и венецот, истакнува Дума.

„Прв од куќата излегувал кумот, кој ја товарел на коњите промената на невестата. Невестата се водела од едно детенце, фатени за рака со шамивче. Откога ќe се качела на коњот, ќе фрлала шеќерки околу неа, а мајката на невестата ќе фрлала ориз по зетот и по невестата. Коњите на зетот и на невестата секогаш биле бели. Откога ќе кинисале (тргнеле) сватовите, девојките од селото ќе почнеле да пеат“ (Дума, 2007, 89).

Вообичаено, кога невестата се разделувала од своите родители се пеела песната „Черешна од корен са корни“, но и други песни, како на пример:

Кинисала Роса на гости да оди,
на гости да оди кај нејни вујковци
ошла до кај пошла синоро германски
на пат ми го сретна нејзиното момче
назад да се враќа од бојното поле
извика од срце убавата Роса,
леле мили боже како да се врна
од сендра ќе падна вујко ќе усрама,
кој ќе му ја дава белата промена
китка накитена со севда проена.

Откако младоженецот и невестата ќе пристигнеле во куќата на зетот, младите требало да застанат среде дворот, без да се симнат од коњите. Потоа, „свекрвата ќе ги измиела со вино и ќе ги подарела со по една риза. Со погача на главата ќе ги свртела младоженците со оро три пати, придружена од поседарките. За да слезе невестата од коњот, се донесувало стол, а на столот се ставал ралник. Кога ќе слезела невестата, требало десната нога да ја стави на ралникот, за да била бериќетлија. Невестата ќе ги подарела (дарувала) сите домашни на свекорот. На свекорот, свекрвата и на кумот им давала кошули, на сите машки свадбари им давала чорапи, на женските - месали, а бракарите ја подарувале со пари“ (Дума, 2007, 90). Потоа, мало детенце ја носело невестата пред влезот на куќата. Притоа, таа носела две торби со погачи со двете раце. На самиот влез требало да се прекрсти и на горниот дел од вратата да направи крст со мед или со шеќер. Потоа, придружена од девојки, влегувала во својата соба, каде што била нејзината руба. Во собата девојките ја разгледувале рубата и пееле. 
По адетите во куќата на младоженецот, невестата и зетот се носеле во црква на венчавање ${ }^{16}$. По завршувањето на венчавката, невестата се носела на вода ${ }^{17}$. Потоа доаѓале младоженците да играат оро што го водел кумот, кој во раката имал шише вино. Играјќи оро, вртеле трипати околку масата, а невестата трипати ќе застанела пред свекорот да говет ${ }^{18}$.

Во понеделникот наутро, невестата придружувана од поседарките, со две мали стомни, пеејќи одела на чешма или на езеро да донесе вода. Од оваа вода пиеле сите домашни и се прскала куќата. Вечерта, пак, се продолжувало со песни и ора, но и со хумористични активности, како на пример маскенбал. Во средата си заминувале поседарките, откако ќе ги дарувал свекорот. Во неделата (една седмица по свадбата), мајката на невестата доаѓала кај зетот за да види во каква фамилија паднала ќерка ѝ, а по некој месец, невестата заминувала кај мајката на поседок. Таму ја носел свекорот или деверот и седела осум дена. Потоа, повторно свекорот одел и ја земал назад.

Обичај било, по свадбата, сите роднини да ги канат зетот и невестата на ручек или на вечера, кои секогаш оделе придружени од машко детенце.

На крајот ќе заклучиме дека свадбените обреди обичаи и песни кај Македонците во Мала Преспа се слични или речиси идентични со свадбените обреди, обичаи и песни на целиот македонски ареал. Во целокупниот свадбен обреден комплекс се наталожени остатоци од некогашните права и должности на жената и нејзината положба во селската заедница, а исто така и старите верувања со магиски и религиозен карактер.

\section{ЛИТЕРАТУРА}

БЕЛЧЕВ, Т. (2016). Речник на туризими, архаизми, дијалектизми и ретко употребувани зборови во македонскиот јазик. Штип: Универзитет „Гоце Делчев“.

ВЕЛИЧКОВСКА, Р. (2008). Музичките дијалекти во македонското традиционално народно пеење. Скопје: Институт за фолклор „Марко Цепенков“", Народни песни, Книга 17.

ВЕЛИЧКОВСКА, Р. (2016). Обредната пејачка традиција во Кратовскиот регион. Кратово: Општинска установа „Музеј на град Кратово“.

ГОЛО БРДО. (2018). Од материјалите на балканската експедиција на РАН и СПбДУ во 2008-2010 година.

\footnotetext{
${ }^{16}$ На венчавката присуствувале: попот, кумот, братимите, свекорот, свекрвата и некои поседарки што ја придружуваат невестата.

${ }^{17}$ Во дворот ќе се наределе софри и на нив седеле постарите свадбари. На чело седел свештеникот со кумот и свекорот. На софрите се ределе мезиња, а на средина бил котелот со вино. Погачата била пред свештеникот, а над неа дулбен и две чаши, за невестата и младоженецот. Во чашите се фрлале метални пари, а на овој адет се пиело само ракија. Гостите од селото носеле овошје, сирење и благо. Парите, кои ги носеле, се фрлале во дулбенот над погачата.

${ }^{18}$ Гувее.
} 
ДУМА, Г. (2007). Мала Пресnа. Скопје: Филолошки факултет „Блаже Конески“.

ЈАНКУЛА, К. (2017). Записи од мојот крај (Долна Преспа, Република Албанија). Скопје: Институт за македонски јазик „Крсте Мисирков“.

КОСТОВ, К. (2004). Дебар и Дебарско низ вековите. Скопје.

ПЕНУШЛИСКИ, К. (1988). Одбрани фолклористички трудови 2. Скопје: Македонска книга.

ПЕНУШЛИСКИ, К. (2012). Историја на македонскиот фолклор. Скопје: Матица македонска.

ПЕТРЕСКА, В. (2000). Семејниот обреден комплекс во Куманово и Кумановско, Фолклорот во Куманово и Кумановско. Скопје: Институт за фолклор „Марко Цепенков“ - Скопје; Центар за култура „Трајко Прокопиев“ - Куманово.

ПЕТРЕСКА, В. (2002). Свадбата како обред на премин кај Македониите од Брсјачката етнографска целина. Посебни изданија, книга 43. Скопје: Институт за фолклор „Марко Цепенков“.

СИМС, М. и СТИВЕНС, М. (2010). Жив фолклор. Скопје: Академски печат.

СПАСЕ, Н. (1995). Македонски народни песни (Мала Преспа). Скопје: Матица македонска.

СПАСЕ, С. (1995). Писма за мојот внук Ариан во Тирана. Скопје: Матица македонска.

ТОДОРОСКА, К. (2014). Македонщите во Албанија (1912-1991). Скопје: Менора.

Andrijana Janevska

\section{THE WEDDING RITUALS OF THE MACEDONIANS IN THE REGION OF MALA PRESPA}

Summary

The most powerful, most emotional, most expressive and most natural tool that man has never left without regard to time, place and age is the folk song. In the whole, the wedding ritual is deposited remnants of former characteristics of social life.

Therefore, in this paper, the subject of the study is the female ritual singing tradition, in order to emphasize the role of women in preserving and continuing the traditional ritual singing culture of Macedonians in the region of Mala Prespa. The wedding ceremony, is a transition from one sex-age group to another, from one social status to another not only for the bride and groom but also for both families, as well as for certain individuals from the wedding ceremony, who by this act become blood relatives. 


\section{Прилози}

\section{1. Нотен и текстуален пример}

Шенвај се, мајко, шенвај се

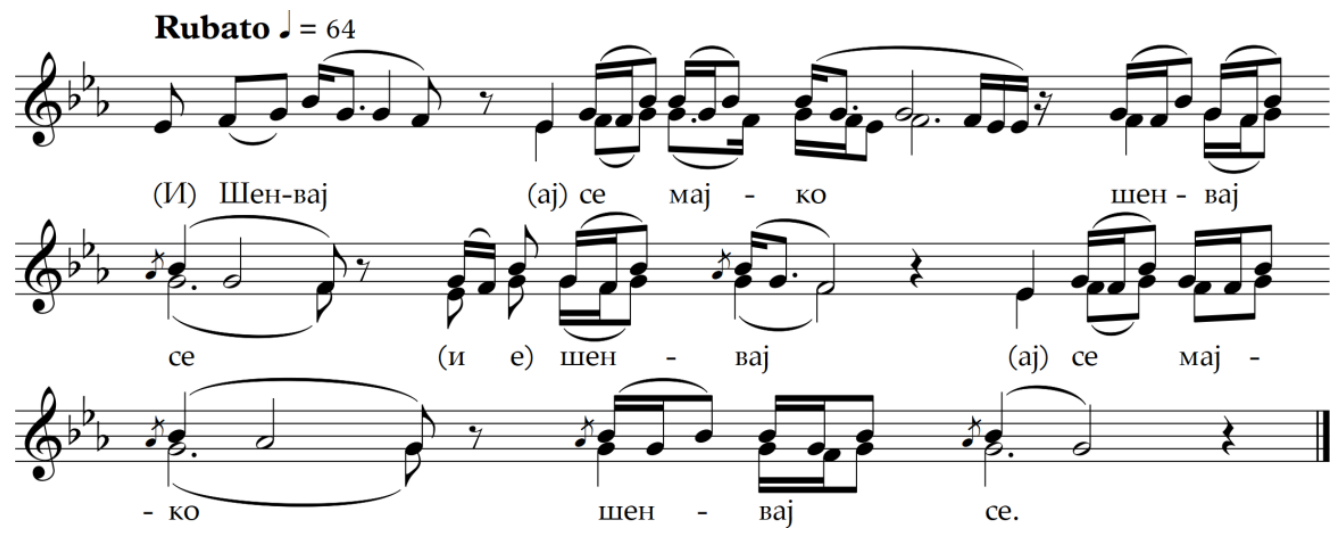

Шенва(ај) се, мајко, шенвај се

(и, е) Шенва(ај) се, мајко, шенвај се!

Још ова вечер со мене,

и утре дур до пладнина!

Дур да ми удри санцето,

дур да ми стани сланата!

Ке дојдет бели сватови,

ќе дојсет зетој ќитени!

Снимено во с. Пустец, Мала Преспа (2014) година. Пеат: Олга Ташовска, Катерина Ташовска и Трена Грозданова. Снимила, дешифрирала, мелографирала Андријана Јаневска. Оваа песна ѝ се пее на девојката во последната седмица пред свадбата кога таа се подготвува за мажење (Забелешка на Стерјо Спасе). 


\section{2. Илустрација}

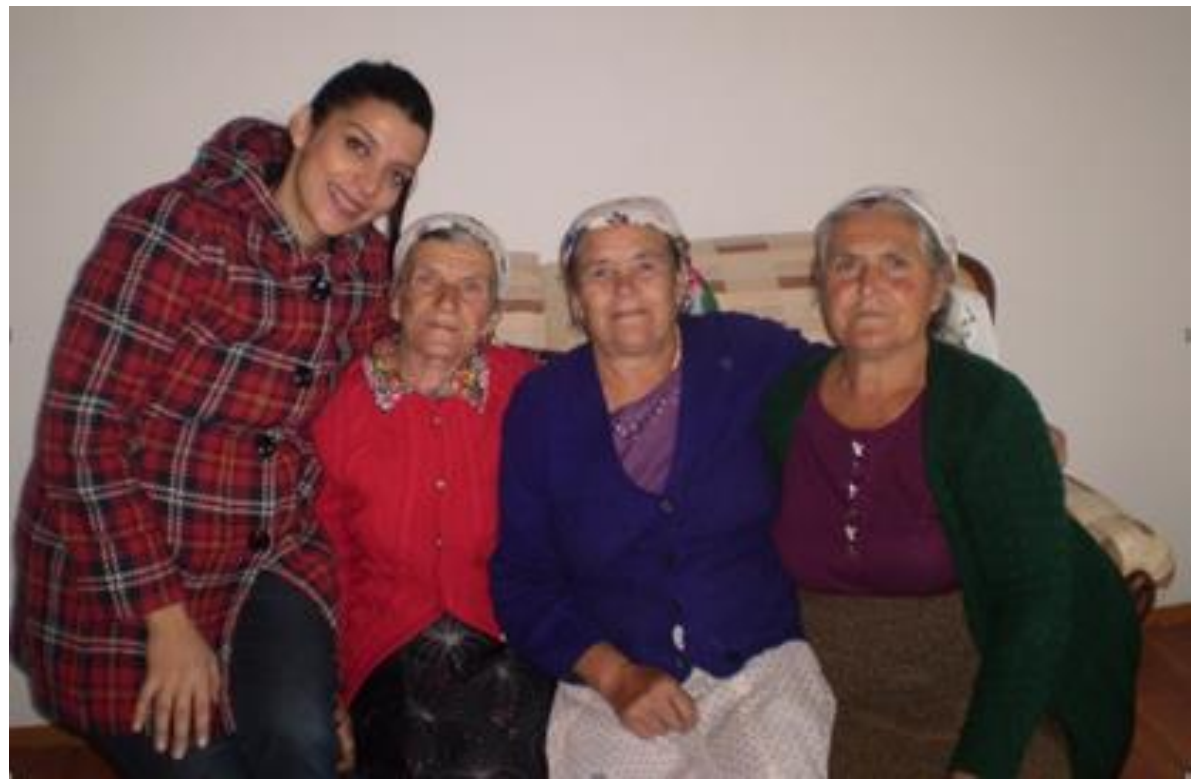

Фотографија 1

Од сопствените теренски истражувања со пејачките Олга Ташовска, Катерина Ташовска и Трена Грозданова во Пустец, Мала Преспа (2014 година). 